\title{
Attitude of Students towards Ethical and Moral Values in Karachi, Pakistan
}

\author{
Dr. Memoona Saeed Lodhi ${ }^{1} \&$ Dr. Jawaid Ahmed Siddiqui ${ }^{2}$ \\ 1 Assistant Professor, Hamdard Institute of Education and Social Sciences, Hamdard University Karachi, \\ Pakistan \\ 2 Dean, Faculty of Humanities and Social Sciences, Hamdard University Karachi, Pakistan
}

\begin{abstract}
Education is the most important factor, which trains students towards social practices and moral ethics. It is not only restricted to pursue degree for economic gain, rather attaining moral values. As the social order is changing,children are more engaged in diverse society and extensively interacting with social media. Sound and value based education in this context has become very crucial to prepare youth to live within ethical boundaries.The research aims to find the attitude of school going students towards ethical goodness. Survey methodology is chosen to conduct a research. The population for the study consists of all the students studying at secondary level in Karachi. The sample size of 200 is selected through random sampling from 5private institutions. The instrument used to obtain data was adapted from The Commitment to Ethical Goodness Scale (Narvaez, Bock \&Vaydich, 2008).The results show that majority of the respondents are positive on greater part of the items of Ethical Identity Scale. The trend among the respondents for majority of the items in Moral Locus of Control \& Ethical Self-Regulation is found to be negative. The results also show that school going children are conscious about their well-being. Attitude of few of the students is uncaring towards teachers and family members. Their liberal decisions are highly influenced by external environment. Majority of the students have uncaring attitude, whereas few are also engaged in unethical activities. Majority of the students follow their own rules. Majority of the students' value ethics.Around half of the students have not learnt about ethics in school. The results conclude that moral education must be imparted to all the school going children to develop ethical practices. Curriculum Wing of Ministry of Educationmust involve teachers to design a separate course of ethics for students.
\end{abstract}

Keywords:Ethics, Domains, Attitude

\section{Introduction}

Theincrease use of technology and cyberspace has become driving tool in shaping the behaviorand social well-being of people. Human are highly mesmerized by the technological revolutions, which has not only improved global interaction, but has also raised unethical practices. There are variousfactors which shape human conduct, which include social relations, friend circle, family environment, culture,etc (Vink, 2012,Triandis\&Suh, 2002). In the view of sociologists, norms, values, customs and social interactions greatly influence human conduct (Blumer, 2004). One of the most important aspects of human personality, which persuade human action, is morality.

Moral development has its philosophical basis dated back to the Greek philosophers. It studies about human nature in realizing social goodness (Blasi, 2004). Several theories are presented on moral development. Earlier, Kant gave theory based on actions and moral rules. His main focus was on the established rules which one need to follow. This theory was highly criticized and disregarded because of obligations imposed on individuals.Later, Piaget divided cognitive development based on moral development, where he categorized ages for morality. Each level is unique and significant; however, the final stage- operational is the highest level individual can attain. He believed that moral development is a developmental process which is based on cognitive development (Pressley and McCormick, 2007).Kohlberg (1978)hypothesiswas based on the previous theories, which highlights moral reasoning through three levels: Pre-conventional level behaviors, which are directed by society and based on social acceptability, whereas individuals follow the directed instructions and perform tasks due to the fear of punishment. Conventional level is directed by society, where human are obliged to follow rules as per set by society, while Post-Conventional level include social contract.

From these theories, it is confirmed that morality is gradually attained through the process of development. Many internal and external factors are involved in influencing moral act. 
Figure 1: Kohlberg Stages of Moral Development

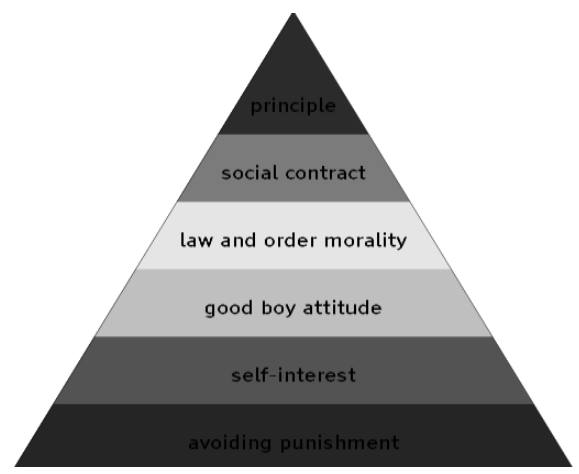

Children are mostly affected by societal changes (KoluckiandLemish, 2011). They adapt everything rapidly. They believe in social interaction and learn new things from their surroundings. Their cognitive and social development has always been the focal point of interest for everyone; however their moral development is often ignored.

The moral development of children begins from their family. When children socialize with their family members, they learn moral values and ethics (Reed, Turiel and Brown, 1996). They develop strong sense of fairness and take rational decision making and practice the same in their daily routine lives.

The moral nature of children is based on imitation. They are good observers and follow others. Many external and internal factors may also affect children personality. Personality traits and many other psychological factors deeply influence their moral reasoning skills. In the presence of morality, their decisions will be in a proper flow, which can help in maintaining healthy relations with society and adjustthemparallel to societal changes.Failing to foster ethical and moral grooming may led to social detachment. The other factors which affect their ethical grooming include socio-economic condition, family issues, cognitive factors (Caravita, Giardino, Lenzi, Salvaterra and Antonietti, 2012; Puka, 1994). Kreps \& Gonzales (2010) say that those children who are maltreated are not groomedmorally and often take wrong decisions in life. Sharma (2013) reported that there is a lack of moral grooming among children these days due to family issues and moral degradation.

The role of parents in this regard is important (Berkowitz andGrych, 1998). Social institutions equally contribute for the moral development of children. One of the most important social institution, which is considered as the basis of moral grooming of child's personality is school. Its role is highlighted by several researchers (Weissbourdet al, 2013; Corbett, 2011). School is the place where children spend most of their time after home. The educational institutions are responsible to provide ethical training to the students. It makes evident that through social interaction in school, their moral development is highly influenced and directed. Weissbourd et al (2013) say that school environment in this regard is very important. The way teacher interact, the background of the classmates, the tactics teachers use to deal with students, the codes and rules, school connectedness, ethics, curriculum, all led in harmonizing moral development.

Society is constantly changing and its impact can be seen from the behavior and attitude of children. Social crimes such as abuses, robbery, killing, use of drugs, bullying, and dishonoring parents have increased in the recent years not only in the western countries but also in Pakistan. The moral corrosion among youth has also been highlighted by Masath(2013). In this regard, it is very crucial to find, how moral development is shaped among the school going children in Pakistan and how society and educational institutions promote ethical practices and contribute for the moral development of students.

\section{Research Methodology}

The study has taken survey research methodology.

Population and Sampling

The population for the present study consists of all the students studying atsecondary level in Karachi. The sample size of 200 is selected through random sampling from 5 private educational institutions of Karachi (40 from each institution).

Research Instrument

The Commitment to Ethical Goodness Scale (Narvaez et al., 2008) has been used to collect data from the respondents. 3-factors (Ethical Identity Scale, Moral Locus of Control and Ethical Self-Regulations) are used. 


\section{Data Analysis \\ Table 1}

Number of participants according to gender

\begin{tabular}{|l|c|c|}
\hline \multicolumn{1}{|c|}{ Gender } & No of Participants & Percentage \\
\hline Male & 100 & 50 \\
\hline Female & 100 & 50 \\
\hline Total & 200 & 100 \\
\hline
\end{tabular}

Table 2

Showing the responses on Scale

\begin{tabular}{|c|c|c|c|c|}
\hline Section A: Ethical Identity Scale & $\mathbf{S A}$ & $\mathbf{A}$ & D & SD \\
\hline Being a good person at school is important to me & 127.0 & 43.0 & 12.0 & 18.0 \\
\hline I respect my teachers and always obey their commands & 40.0 & 87.0 & 32.0 & 41.0 \\
\hline I learnt about ethics in school & 72.0 & 35.0 & 56.0 & 37.0 \\
\hline People at school think I'm a good person & 44.0 & 39.0 & 109.0 & 8.0 \\
\hline Being a good person at home is important to me & 19.0 & 12.0 & 127.0 & 42.0 \\
\hline People at home think I am a good person & 117.0 & 72.0 & 9.0 & 2.0 \\
\hline I know what it means to be a good person at home & 51.0 & 69.0 & 59.0 & 21.0 \\
\hline I am a good person at home & 119.0 & 44.0 & 33.0 & 4.0 \\
\hline I am a good person with my friends & 132.0 & 9.0 & 49.0 & 10.0 \\
\hline I agree with most of my friends on what it is to be a good person & 16.0 & 99.0 & 36.0 & 49.0 \\
\hline \multicolumn{5}{|l|}{ Section B: Moral Locus of Control } \\
\hline It doesn't matter whether you are good or bad. & 97.0 & 74.0 & 26.0 & 3.0 \\
\hline I don't mind doing bad sometimes & 37.0 & 89.0 & 43.0 & 31.0 \\
\hline I do what my friends do. & 120.0 & 39.0 & 10.0 & 31.0 \\
\hline \multicolumn{5}{|l|}{ Section C: Ethical Self-Regulation } \\
\hline I have rules for myself that I follow. & 188.0 & 9.0 & 1.0 & 2.0 \\
\hline I behave badly & 39.0 & 47.0 & 114.0 & 0.0 \\
\hline Ethics have no value in my life & 21.0 & 39.0 & 107.0 & 33.0 \\
\hline When things go wrong, it's other people's fault. & 109.0 & 82.0 & 4.0 & 5.0 \\
\hline I often speaks truth & 39.0 & 78.0 & 70.0 & 13.0 \\
\hline
\end{tabular}

Table 3

Showing the Mean and Standards Deviation of Scale

\begin{tabular}{|l|c|c|c|}
\hline & N & Mean & Std. Deviation \\
\hline SA & 18 & 77.0556 & 49.91224 \\
A & 18 & 53.6667 & 28.45636 \\
D & 18 & 49.8333 & 40.54663 \\
SD & 18 & 19.4444 & 16.40740 \\
Valid N (list-wise) & 18 & & \\
\hline
\end{tabular}

\section{Results}

1. Majority of the respondents are positive on greater part of the items of Ethical Identity Scale

2. The trend among the respondents for majority of the items in Moral Locus of Control \& Ethical SelfRegulation is found to be negative.

3. Being a good person at school is important for most of the students.

4. Majority respect their teachers and obey their commands, but good number of students do not follow it.

5. Half of the respondents learnt about ethics in school, while the rest half disagreed.

6. Majority of the students perceived others opinion about their personality as negative at school.

7. Majority of the students do not value being good at home, however majority agreed that they know the importance of being good at home. In addition to that, majority of the students also agreed that they are perceived as good by their family members as well as by their own self.

8. Majority value friendship and and are influenced by their friends.

9. Majority engaged themselves in unethical practices at times.

10. Majority have don't care attitude about others.

11. Majority of the students set their own rules to follow.

12. Majority avoid misbehavior. 
13. Majority value ethics in their lives.

14. Majority blame others for faults.

15. Majority do not speak truth often

\section{Discussion}

Moral Development is the foundation stone for social interaction (Berger, 2005; Koenig, Cicchetti\&Rogosch, 2004). It not only builds rapport, but also provides social satisfaction to individuals. The social adjustability gradually shifts by time and links to the sense of maturity in understanding and responding to the situations. Exposing individuals to morality help to reap socially interactive human, which are welladjustable in society and morally groomed for gaining good rapport from surrounding.

Moral development is very important for children. Many factors are involved in the moral development of children including self-control and self- esteem (Berkowitz \&Grych, 1998). Since children are energetic and active, self-control over various occasions is crucial to judge their adjustability to environment. Their limitations are unbounded and their decisions are often influenced by others. Additionally, self-esteem is so crucial that a single word of de-motivation can led them towards negative feeling and unethical practices. It makes evident that their decisions may lead to unethical practices, if not directed by social institutions.

From the table, section A, it is concluded that majority of the students strongly agree that it is crucial for them to be good amongst their school mates. It shows that students are possessive about their self-esteem and their rapport among the people involved at school. Self- esteem is very important for children. It comes in children from environment. They learn about self-esteem from school and from family. It helps to develop selfcontrol skills, kindness, patience, peace and love. Those children who believe in self-esteem are highly confident, generate positive thinking and make better decisions in life (Brooks, 2012, Hannell, 2012). Majority of the students agreed that it is wise to obey the command of teachers, however a good number of respondents also disagree with the same statement. It reflects that unethical practices prevail among few of the school going children and their attitude with teachers is not as good as it is expected. Majority of the students do not value being good at home, however majority agreed that they know the importance to be good at home, whereas majority also agreed that they are perceived as good by their family members as well as by their own self.

Half of the students learnt about ethics in schools, whereas the rest did not. Moral education is the pillar of ethical grooming. It is often termed as religious or character education. It is the critical domain, which helps to shape the behavior of students. The importance of moral education is highlighted by various studies (Braspenning, 2010,Oladipo, 2009, Larson, 2009, Halstead \& Pike, 2006, Gardner, Cairns and Lawton, 2003). Several countries initiated moral education as the core subject in school education, which contributed in the moral development of children (Balakrishnan, 2010). In western countries, the concept of moral education is not well practiced, but in the eastern countries such as Pakistan, moral education is provided to the students in the form of subject of ethics (Islamiat- Religious teachings). Children are taught about goodness and about attributes of moral well-being. Unfortunately, moral education alone is not reaping best products as children are involved in unethical practices these days. The same is found by this research.

Majority of the students perceive others opinion about their personality as negative at school. This notion shows that their attitude or their lives are molded in such a manner that their gestures and act are unaccepted for many. It eventually leads them to engage in unethical practices in order to seek attention of others or to prove others wrong. Majority is good with their friends and knows how to maintain rapport with them.

From the table, section B discloses that majority have don't care attitude towards others. Few are also engaged in unethical social activities, whereas majority follows their friends in taking decisions. It shows that their friend circle highly impact their behavioral pattern.

From the table, section $\mathrm{C}$ discloses that majority follow their rules. Majority do not speak truth whereas majority blames others for wrong act. All these three issues reflect presence of unethical practices.

\section{Conclusion}

Weissbourd et al. (2013) suggested that school can nurture moral and ethical grooming by prioritizing student teacher relationship, by providing opportunities for students to practice skills, by providing them leadership role, by using discipline strategies, by conducting regular assessment for values and by dealing with issues intelligently. Students in Pakistan must also be given chance to have their say. They must also be provided with moral education training.

\section{Reference}

[1]. Balakrishnan, V. (2010). The Development of Moral Education in Malaysia. Asia Pacific Journal of Educators and Education, 25, 89-101

[2]. Berger, K. S. (2005). The play years: Psychosocial development. In C. Gardner \& R. Falk (Eds.), The Developing Person: Throughout the Life Span (pp. 237-262). New York: Worth Publishers. 
[3]. Berkowitz, M.W., \&Grych, J.H. (1998). Fostering Goodness: Teaching Parents to Facilitate Children's Moral Development. Journal of Moral Education, 27(3), 371-391.

[4]. Blasi, A (2004). "Moral functioning: Moral understanding and personality" In D. K. Lapsley and D. Narvaez (Eds.), Morality, Self, and Identity Mahwah, NJ: Erlbaum.

[5]. Blumer, H. (2004). George Herbert Mead and Human Conduct. Rowman Altamira.

[6]. Braspenning, M. (2010). An Exploration of Religious Education and its Importance for Moral Development in Children. Social Cosmos, 1.

[7]. Brooks, Y. (2012). Building Your Child's Self- Esteem. iUniverse.

[8]. Caravita, S.C., Giardino, S., Lenzi, L., Salvaterra, M., \&Antonietti, A. (2012). Socio-economic factors related to moral reasoning in childhood and adolescence: the missing link between brain and behavior. Frontiers in Human Neuroscience, 6, 262.

[9]. Corbtt, R.D. (2011). An exploration of the school's role in moral development (Ph.D dissertation). Simon Fraser University.

[10]. Gardner, R., Cairns, J., \& Lawton, D. (2003). Education for values: morals, ethics and citizenship in contemporary teaching. Routledge.

[11]. Halstead, J.M., \& Pike, M.A. (2006). Citizenship and moral education: values in action. Routledge.

[12]. Hannell, G. (2012). Promoting Positive Thinking: Building Children's Self-Esteem, Self Confidence and Optimism. Routledge.

[13]. Koenig, A. L., Cicchetti, D., \&Rogosch, F. A. (2004). Moral development: The association between maltreatment and young children's prosocial behaviors and moral transgression.

[14]. Kohlberg, L. (1978). Revisions in the theory and practice of moral development. New Dimensions for child development 2. San Francisco: Jossey-Bass.

[15]. Kolucki, B., \&Lemish, D. (2011). Communicating with Children-Principles and Practices to Nurture , Inspire, Excite, Educate and Heal. UNICEF

[16]. Kreps, J.J., \& Gonzalez, T. (2010). The Effects of Maltreatment on Children's Moral Development. (unpublished thesis). Faculty of the Psychology and Child Development Department California Polytechnic State University, San Luis Obispo

[17]. Larson, K. (2009). Understanding the Importance of Character Education (Mastersthesis). The Graduate School, University of Wisconsin-Stout.

[18]. Masath, F.B. (2013). Moral Deterioration: The Reflection on Emerging Street Youth Gangs in Musoma, Tanzania. Academic Research International, 4(1), 101-111.

[19]. Narvaez, D., Bock, T., \&Vaydich, J.L. (2008). Guide forusingtheCommitmenttoEthicalGoodnessscaleforElementary and SecondarySchoolStudents. Notre Dame: University of Notre Dame

[20]. Oladipo, S.E. (2009). Moral Education of the Child: Whose Responsibility? Journal of Social Sciences, 20(2), 149-156

[21]. Pressley, M., \& McCormick, C.B. (2007). Child and adolescent development for educators. New York: The Guilford Press.

[22]. Puka, B. (1994). Moral Development: New Research in Moral Development. Taylor \& Francis

[23]. Reed, E.S., Turiel, E., \& Brown, T. (1996). Values and Knowledge. Psychology Press.

[24]. Sharma, J. (June 9, 2013). Moral Values among Adolescents. Daily ExcelsiorSocial Development, 13(1), 97-106.

[25]. Triandis, H.C. \&Suh, E.M. (2002). Cultural Influences on Personality. Annu Rev. Psychol, 53, 133-160

[26]. Vink, P. (2012). Advances in Social and Organizational Factors. CRC Press

[27]. Weissbourd, R, Bouffard, S.M. \& Jones, S.M. (2013). School Climate and Moral and Social Development. National School Climate Center. 